\title{
Efforts to Prevent the Conflict in the Succession of the Family Business Using the Strategic Collaboration Model
}

\author{
Efrijal Adil \\ Department Management, Faculty of Economic \& Business, Universitas Pembangunan Panca \\ Budi, Medan, North Sumatera, Indonesia \\ E-mail: efrijaladil@dosen.pancabudi.ac.id
}

\begin{abstract}
Samrin
Department Management, Faculty of Economic \& Business, Universitas Pembangunan Panca Budi, Medan, North Sumatera, Indonesia

E-mail: samrin@dosen.pancabudi.ac.id
\end{abstract}

Muhammad Dharma Tuah Putra Nasution

Department Management, Faculty of Economic \& Business, Universitas Pembangunan Panca Budi, Medan, North Sumatera, Indonesia E-mail: dharma_nasution@dosen.pancabudi.ac.id

\section{Yossie Rossanty}

Department Management, Faculty of Economic \& Business, Universitas Pembangunan Panca Budi, Medan, North Sumatera, Indonesia E-mail: yossie_rossanty@dosen.pancabudi.ac.id

Received: Nov. 10, 2017 Accepted: Nov. 15, 2017 Published: Nov. 29, 2017 doi:10.5296/bmh.v5i2.12206ＵRL: http://dx.doi.org/10.5296/bmh.v5i2.12206

\section{Abstract}

The issue of succession is important news if there is a generation that involved more than one 
man. Of course, the possibility of dispute occurs as a result of the difference in the perspective of the successor generation when running the business. The proposed research aims to demonstrate how the process of succession in the family business with Strategic Collaboration Models (SCM). This research includes descriptive qualitative research. The data will be collected with the interview and selection of informants using the purposive sampling technique. In this proposed research, the informants are the founder generation that including family business leaders and potential successor. The result of this research is expected to explain the process of succession through strategic collaboration model. Three phases need to be addressed when the process of succession already from input, process, and output. The input stage is more advancing in training, guidance and direction program for the successor generation. In the process, stages explain how the founder generation can identify the interest and talents of the successor generation. This case is aimed to know whether the business existence related to interest and talent for the successor generations. In output stage will explain how the founder generation and the successor ability to calculate about how much financing required to build a new business. In the family business allows a conflict, so it necessary anticipates with how about the existence of an agreement can separate the business from the founder generation with the business from the successor.

Keywords: Family business leader, Successor, Succession, Conflict, Strategic collaboration model 


\section{Introduction}

In a note by Poza (2013) revealed that 64 percent of GDP in the United States is a significant contribution from the family business. While in the other countries the number reached 75 percent of GDP. The contribution value of the family business in the world contribute between $80 \%-98 \%$ of GDP. The family business has been able to accommodate more than 85 percent of the workers in the world. This data in line with the statement from the Shepherd (2000) who described that the family business has proven supporting economic in the world. Although, the operation of the family business is more complicated than the outside of the family business.

The family company often has a problem in the management of succession when the business founder or management from the current generation has been managing the family business and they almost near retired. If the generation afterward took over management, there is a possibility that there is a gap between the ownership and controllable the business with skills required and working to sustain the company as responsible for their family (Moores, \& Barrett, 2002). Succession planning allows finding the knowledge related to the business details. The knowledge of successor can assist the successor to implement the leadership model in the business (Lipman, 2010).

The development of a family business is unfree from the influence of the leadership succession, that will be conducted with each generation as well. Moreover, there is the engagement of two or more generations in the business. It showed the implementation of the dynamic interaction in a family, but it had an impact on the decision making (Hess, 2006). The process of succession can be mentioned a complicated situation. As a result of the difference in the viewpoint when managing a business. There are the differences in the vision and mission as well as character of the successor generation in the family business. Even De Massis (2008) asserts that the mistake in managing the family business can generate a conflict due to mismatch, misunderstanding when they felt the situation is unfair treatment. Such conflict is also called relation factors conflict. The conflict becomes the obstacles in the process of succession from the family business.

\section{Literature Review}

Hoover \& Hoover (2013) stated three elements influence in the family business, namely:

\section{1) Family}

The family business success is measured in the sense of harmony, unity, and development of the individual who is pleased with regard substantial and positive.

\section{2) Business}

The entities of economic where the success is not measured by self-esteem and interpersonal pleasure of the individual, but in productivity and professionalism. So the primary measure of a person lies in contributing to the strategy implementation, achieve the target and the company's profitability. 
3) Ownership

Based on the role of a person for investment, minimize risk, as the company representative to make a deal with the other party.

Succession management transferred in business process from the founder generation to the successors. The family business success needs to management transfer. Therefore, succession is a critical phase and it determines to continuity in a family business. On the other hand, succession is a sensitive theme to anticipate a conflict and disorder in a family business. Succession is a problem that needs to an analysis in the various perspectives such as the perspective of the family, management and the owner. The comprehensivity to understand precisely the different interest from owners or stakeholders (Brockhaus, 2004). Besides, the succession plan means to identify the critical management position. It started from the level of project manager and supervisor to expand the highest position in a company. The family company must have succession plan where the company must be able to determine the timing to make a plan and implement succession. In the study of Ismail (2009) explained that the experts highlighted the process of succession planning in family business. The factors must pay attention in the process of succession: 1) How the level of readiness for the business successors; 2) How the level of a harmony in family relationships: 3) How they make plan and control in an activity. The successor generation must be trained communication skills before they forward business. Therefore it is a crucial chain to be a better communicator so that the relationship among the successor generation is still established. Fishman (2008) emphasizes the importance of the value of communication and comprehensiveness in an election process by the successor to avoid a conflict in the family business (Mutunga \& Gachunga, 2013). A business must have a clear purpose and plan to maintain the sustainability of business survival. There are five steps in planning for the success of the highlighted by Grassi Jr \& Giarmarco (2008):

- Determine the long-term goal of the company owner.

- Design the financial needs to ensure the financial security.

- Determine who will manage the business and develop the management team.

- Determine who will own the businesses have similar interests.

- Minimize income tax and the appropriate ownership plan.

The implementation of succession plan depends on the process of selecting and the process of preparing the successor. The process of selecting the successor related to the value of communication and objectivity. While the process of the preparing the successor addressed about the Successor Development Program and allowance from the previous Family Business Leader (Fishman, 2008). The values are in the process of selecting the successor is as follows:

1) Communicative

The primary value in selecting the successor is always communication about a succession 


\section{Macrothink}

Business and Management Horizons

ISSN 2326-0297

2017, Vol. 5, No. 2

plan for family members and the parties concerned as early as possible and sensitive reactions may arise within the family members.

\section{2) Objective}

Family Business Leader must conduct the election successor related to identify the necessary factors to run a business effectively. These factors are as follows:

- Passion

- Competency

- Aptitude

- Vision

- Empathy

After the selection process, successor Fishman (2008) emphasized that the value of variables and indicators as follows:

\section{1) Successor Development Program}

Family Business Leader needs to have Successor Development Plan to avoid the feeling that appears as a result of power shift. In the Successor Development Plan, Family Business Leader highlighted three things which much be transferred namely:
a. Transfer of Wisdom
b. Transfer of Responsibility
c. Transfer of Authority

Successor Development Plan must have a benchmark in the process of the skills development and experience that includes various fields in the company. Family Business leaders can show the purpose and plan that will be reached in the process of the development of the skills and experience to the successor.

2) Allowance from Previous Family Business Leader

It can be seen from the following indicators:

a. There is the announcement of the plan back from the Family Business Leader after a plan of succession.

b. There is the willingness of Family Business Leaders to hand over the authority that belonged to the successor.

c. There is the readiness of the Family Business Leaders to tolerate successor failure in the learning process.

Casillas \& Moreno (2007) states that the potential successor will be better if given the opportunity to work on an essential part of the family business. The potential successor will 
have an experience for a continuation of their business activities.

One of the strategies in the process of succession that combines mentoring as an essential mechanism to build and develop leadership and succession in the family businesses which called Strategic Collaboration Model (SCM). The stage in SCM model refers Haynes (2008) consists of several stages, preconditions, strategic collaboration team, interpersonal skills training, strategic collaboration contract, discovery, dream, design, and delivery.

\section{- Preconditions}

The objective is to ensure the condition of the company's resources. At this stage identified the necessary support to prepare the successor generation to become a leader in business. It provided in term form of capital. The capital was given to build a different business. Also, another support is instruction in technical and non-technical. Business redirection adjusted with the portion of the field and business that will be controlled. Such as how to face the question of the business, how working method leader, how to overcome the employees, who do not work in line with the vision and mission of the company, how should leaders responsible, how should be and how to deal with the client. In the simple, the function of this instruction is to make the successor of the candidates can do something by what is desired and what they should be doing. The company can deliver the consultant in the process of the training to the candidates for the successor of the business.

\section{- Strategic Collaboration Team}

\section{Teaching and Coaching Founder Successor}

The stage where the management of the founder of assisting the successor to align the vision and mission that will be embraced. This phase is conducted through the program coaching, mentoring and training and it aims to ensure the potential business leaders who have skills and competencies necessary for the family business.

\section{Successor want to build career}

Successor wants to build a new business which is different business based on their view that will be developed, and it has the bright prospects.

\section{- Interpersonal Skills Training}

\section{Active listening}

Active listening is one of the interpersonal skills. It does not only focus on the speakers, but it shows the verbal and non-verbal signal. Active listening is the main characteristics of a leader that affect a person has a good listening skill and his attitude in delivering the message. It aims to build relationships and illustrates that the leader is the one who appreciates prating opponents.

\section{Communication}

The frequency of communication determines how to do well the relationship between family members (Aronoff \& Ward, 1993). The family will provide the ideas and suggestions that 
will build and bring the company in a better direction. Leaders and communication are the two things related to one another. Business leaders must have ability communication, and they can coordinate with the members. The ability to communicate effectively is one of the essential aspects of leadership qualities.

\section{Feedback}

Good communication related to feedback. Feedback is information about the behavior of the past but delivered at this time, and it is possible to affect behavior at the time to come. The leader must have the skills of feedback is due, without any feedback from the leader, then employees cannot reflect, change, and learn something in work. Family business leaders will teach the candidates for the successor of how to give feedback to the subordinate.

\section{Managing Conflict}

The conflict that happened in a company must be solved because it will give an enormous impact on the success of the company (Morris et al., 1997). After the process of succession, it is essential to see the state of family relationships in the company, whether a conflict occurs between the new leaders with other family members in the company.

The family business leader will give the direction of how a leader to seek solutions to resolve the conflict through both instinct or the soul of his leadership. How is the attitude that must be done by the leader when conflicts occur within the organization, what the most appropriate strategy to resolve the conflict.

\section{- Strategic Collaboration Contract}

The responsibilities of team members

The responsibility of the founder and the successor was the main things. Especially a leader can show a good attitude to the officials in carrying out their duties. The successor of the candidates can be responsible for the work of the given diligent and able to be a good leader must complete in all work field.

\section{Commitment regular meeting}

Regular meetings between founders and successors of each month aimed at evaluating the performance of the successor and feedback from the founder. The founders of the business can directly evaluate and advise on what the shortage of successors. Conversely when the successor generation had trouble can directly ask the business founder.

\section{- Discovery}

This stage is part of the most important of the process of succession plan on family business. This phase is to find what interesting candidates for the successor of the communication results from family business leader to a potential successor.

\section{- Dream}

A dream is an important step in the process of succession plan on family business. This step 
is done by knowing the talent and the interest of potential successor. After knowing the talent and interest, they will identify the business prospects and suitable for the successor generation.

\section{- Design}

The stage where the level of a dream has determined the business design. The purpose is all plan, and target can be achieved by the desired.

\section{- Delivery}

This stage is to establish and provide mentoring, planning and training in business. The role of the family business leader is to assist in building a new business relationship with the financing required, the number of employees will be used, the suitable for the business location.

\section{Methods}

The research will be used a descriptive qualitative research which aims to analyze data with how to describe or illustrate data has been appropriately collected without intending to conclude generalizations. The researcher chose the descriptive qualitative research due to will know and obtain the valid information related to research topic (Sugiyono, 2013). The subject of this research is the Family Business Leaders in plantation company, North Sumatera. In this research, researchers determine the informers by using the purposive sampling method which means the sampling data source using certain considerations. The data source from a semi-structured interview to informers from the family-own company. Thus the authors collected data will be more able to capture the phenomenon holistically. The test of validity data using triangulation, which means the author check data obtained from several sources (Azwar, 1998).

\section{Discussion}

The process of succession in the family business has a potential conflict which includes:

\subsection{Conflicts in Parent-child Relationship}

In succession plan, the quality of the relationship between the leader and the potential successor needed. The relationship between the family business leader with a succession of research will be arranged which is unexpected to lead to conflicts between the family business leader and the potential successor. The family conflict is bound to happen when the process of succession. This case is possible due to the vision and mission of the successor generation do not in line with the founder or initial generation. Founder generation should be aware that the process of succession enables a conflict due to a gap generations, it causes different of ideas, methods, and perspectives. Efforts to resolve the conflict is to prove and convince the founder generation that the successor will be running any business without abandoning the values that have been built by the founder generation. Manage our business responsibly by the vision and mission of the company, despite the need for improvement or renewal of the system to more effectively and efficiently. Business succession can run the 
business activities by adding new ideas creatively. Another conflict can occur in the process of succession are mentioned conflicts among family members.

\subsection{Conflicts among Family Members}

The smoothness of the succession process affect by how harmonious relationship in the family. Conflicts between family members occur because of rivalry between the brothers and the result of multiple leadership within the company. The conflict between successors may occur due to problems at work and outside of work. In addressing existing conflicts, needed a few things such as openness, a maturity of each generation successor. The main strength of the family business is how close kinship and communication exists in developing the family business. De Massis et al. (2009) suggested that a conflict between the successor can be avoided with separate the business between the founder generation and the successor.

\section{Conclusion}

The process of succession using strategic collaboration models to avoid conflicts between the founder generation and the successor generation in the family business. The process of succession within the business separation that will be carried out in several stages:

\subsection{Preconditions}

The input stage is an implementation of the succession, the predetermined conditions resources, and support of the company. The potential successor provided with capital and adequate resources

\subsection{Strategic Collaboration Team}

The stage which the founder generation to provide training and mentoring to the prospective successor. In the process of training and mentoring, the family business leader can do directly. Similarly, succession desires to build their career, where the successor business can choose according to their interests and talents without pressure.

\subsection{Interpersonal Skills Training}

The stage is conducted by training activities, related to increasing the interpersonal skills of a potential successor. Also, training can be done by teaching how to listen actively, how to be a good communicator, how to give a feedback and methods in managing conflict. Founder generation can provide direction to the potential successor and engage them in a meeting with the colleague. Therefore they involve the prospective successor in the process of the decision-making and to engage in resolving conflicts.

\subsection{Strategic Collaboration Contract}

The input stage is a set goal in short-term and long-term, to responsible for carrying out the routine meetings. The company goals establish a business in the short term, and it includes the introduction and the internal company restructuring. The long-term goals are the company's business scale in expansion and development of business. The routine meeting aims to evaluate and provide advice directly to the business successor. 
5.5 Discovery, Dream, Design

This stage is the process of succession using Strategic Collaboration Model. Discovery; the founder generation wants to identify the successor's interests and talents in the business. Later, dream; the founder generation and the successor generation will discuss the appropriate to consider the future business opportunities and prospects, as well as the financing needed in the business. Then, design; the founder generation will design for any business to see the potential and prospects in business, and the family business leader will support the capital in business

\subsection{Delivery}

This stage is output in the process of succession, to build a business in their planning. Therefore business plan is necessary seen from some financing needed, and the number of employees will be used and the match location in business.

\section{References}

Aronoff, C., \& Ward, J. (1993). How families work together. Marietta: Business Owner Resources.

Azwar, S. (1998). Metode Penelitian jilid 1.

Bracci, E., \& Vagnoni, E. (2011). Understanding small family business succession in a knowledge management perspective. IUP Journal of Knowledge Management, 9(1), 7.

Brockhaus, R. H. (2004). Family business succession: Suggestions for future research. Family Business Review, 17(2), 165-177. https://doi.org/10.1111/j.1741-6248.2004.00011.x

Casillas, J. C., Acedo, F. J., \& Moreno, A. M. (2007). International entrepreneurship in family businesses. Cheltenham: Edward Elgar Publishing.

De Massis, A., Chua, J. H., \& Chrisman, J. J. (2008). Factors preventing intra-family succession. Family Business Review, 21(2), 183-199. https://doi.org/10.1111/j.1741-6248.2008.00118.x

Fishman, A. (2008). 9 Elements of Family Business Success: A Proven Formula for Improving Leadership \& Relationships in Family Businesses. New York: McGraw Hill Professional.

Grassi Jr, S. V., \& Giarmarco, J. H. (2008). Practical succession planning for the family-owned business. J. Pract. Est. Plan., 10, 27.

Hess, E. D. (2006). The successful family business: A proactive plan for managing the family and the business. Pennsylvania: Penn State Press.

Hoover, E. A., \& Hoover, C. L. (2013). Getting along in family business: The relationship intelligence handbook. London, New York: Routledge.

Indrawan, M. I., Nasution, M. D. T. P., Adil, E., \& Rossanty, Y. (2016). A Business Model Canvas: Traditional Restaurant "Melayu" in North Sumatra, Indonesia. Business 


\section{Macrothink}

Business and Management Horizons

ISSN 2326-0297

2017, Vol. 5, No. 2

Management and Strategy, 7(2), 102-120. http://dx.doi.org/10.5296/bms.v7i2.10193

Ismail, N., \& Mahfodz, A. N. (2009). Succession planning in family firms and its implication on business performance. Journal of Asia Entrepreneurship and Sustainability, 5(3), 86.

Lipman, F. (2010). The family business guide: everything you need to know to manage your business from legal planning to business strategies. Berlin: Springer. https://doi.org/10.1057/9780230111806

Moores, K., \& Barret, M. A. (2002). Learning family business: paradoxes and pathway. Aldershot UK: Ashgate Publishing.

Mutunga, F., \& Gachunga, H. (2013). Factors affecting succession planning in small and medium enterprises in Kenya. International Journal of Academic Research in Business and Social Sciences, 3(8), 285. http://dx.doi.org/10.6007/IJARBSS/v3-i8/143

Poza, E. J. (2013). Family business. Boston: Cengage Learning.

Shepherd, D. A., \& Zacharakis, A. (2000). Structuring family business succession: An analysis of the future leader's decision making. Entrepreneurship: Theory and Practice, 24(4), 25-25.

Sugiyono, P. D. (2013). Metode Penelitian Manajemen. Bandung: ALFABETA, CV.

Ward, J. L. (2002). Just what is a family business?[w:] In C. E. Aronoff, J. H. Astrachan, \& J. L. Ward (Eds.), Family Business Sourcebook.

Whatley, L. (2011). A new model for family owned business succession. Organization Development Journal, 29(4), 21.

\section{Copyright Disclaimer}

Copyright for this article is retained by the author(s), with first publication rights granted to the journal.

This is an open-access article distributed under the terms and conditions of the Creative Commons Attribution license (http://creativecommons.org/licenses/by/4.0/). 